DOI: $10.17805 /$ ggz.2019.2.2

\title{
Два лика русской идеи в свете тезаурусного подхода
}

\author{
А. А. Горелов
}

Институт философии РАН,

T. А. Горелова

Московский гуманитарный университет

В статье, подготовленной на основе доклада на III Академических чтениях памяти Вл. А. Лукова «Тезаурусы и проблемы культурыл» (МосГУ, 4 апреля 2019 г.), представлен тезаурусный анализ русской идеи, в которой выделяются два антиномичных набора конщептов - Ф. М. Достоевского и Л. Н. Толстого. Если Достоевский соединил в русской идее русскость и общечеловечность, акиентируя внимание на первой части своего утверждения, то Толстой основное внимание уделил общечеловечности русской идеи.

Ключевые слова: русская идея; тезаурус; тезаурусный подход; патриотизм; почвенничество; русский сочиализм; самоотречение; Ф. М. Достоевский; Л. Н. Толстой; В. С. Соловьев

\section{Two Faces of the Russian Idea in the Light of the Thesaurus Approach}

A. A. Gorelov

Institute of Philosophy, Russian Academy of Sciences,

T. A. Gorelova

Moscow University for the Humanities

The article comprises the main points of the paper presented at the $3 \mathrm{rd} \mathrm{Aca-}$ demic Readings in the Memory of Vladimir A. Lukov "Thesauri and Issues of Culture" (Moscow University for the Humanities, April 4, 2019). It features a thesaurus analysis of the Russian idea, in which the authors highlight two antinomic sets of concepts - those of Fyodor Dostoevsky and Leo Tolstoy. If Dostoevsky combined Russianness (russkost') with common humanity, focusing his attention on the first part of the assertion, then Tolstoy concentrated on the universal character of the Russian idea.

Keywords: Russian idea; thesaurus; thesaurus approach; patriotism; pochvenichestvo; Russian socialism; selflessness; F. M. Dostoevsky; L. N. Tolstoy; V. S. Soloviev 


\section{ВВЕДЕНИЕ}

Русская идея в широком смысле - это продукт коллективного творчества многих мыслителей на протяжении сотен лет, в котором можно выделить три этапа. Первый связан с именем Ф. М. Достоевского, который является автором словосочетания «русская идея». Второй этап можно назвать этапом В. С. Соловьева, который развил это понятие в брошюре «Русская идея» - первом произведении под таким названием. Третий этап можно назвать этапом Н. А. Бердяева, которому принадлежит первая книга под названием «Русская идея». Современный, четвертый, этап развития понятия «русская идея» продолжается со второй половины XX в. по настоящее время. Интерес к данной теме многих современных философов показывает глубинную связь русской идеи с другими философскими концептами.

Существовали и социальные предпосылки формирования русской идеи. По особенностям своего местоположения русские - народ не европейский и не азиатский, который вынужден синтезировать в своей культуре оба эти элемента. Культурный синтез может быть обеспечен особыми свойствами национального характера, которые у русских проявляются как широта, максимализм, мессионизм и др. (Горелов, 2014). Общечеловеческую миссию русских как народа можно видеть в единении европейской и азиатской жизни. Одним из путей реализации этого объединяющего потенциала и стала русская идея.

Создание собственно русской идеи - это результат осознания своего предназначения уже сформировавшейся нацией. Для ее формулирования недостаточно быть просто философом, т. е. любить мудрость, а надо тонко чувствовать и любить свой народ. Честь создания русской идеи принадлежит многим русским писателям и мыслителям конца XIX — начала XX в., но ее антиномичные концепции были предложены двумя писателями-мыслителями - Ф. М. Достоевским и Л. Н. Толстым. Эти концепции представляют два лика русской идеи, показывающие разные способы преодоления душевной стихии в развитии русского характера через возможность их диалектического единства на основе русской идеи. В качестве подходящей методологии для анализа обширного и противоречивого материала использован тезаурус как определенная организационная структура. Нами ранее была показана плодотворность данной методологии при анализе сходных проблем - структурного ядра русского национального характера (Горелова, 2015) и структуры цивилизационных концепций Н. Я. Данилевского и О. Шпенглера (Горелов, Горелова, 2017). В данной работе мы стремимся показать значимость тезаурусного подхода для сравнения трактовок одной и той же проблемы - русской идеи - с позиции двух гениев Ф. М. Достоевского и Л. Н. Толстого, без- 
условно ощущающих себя представителями данного народа и стремящихся внести вклад в его будущее.

\section{ОСОБЕННОСТИ ТЕЗАУРУСА КАК МЕТОДОЛОГИИ СРАВНИТЕЛЬНОГО АНАЛИЗА}

Тезаурус («полнота», «накопление», «богатство», «достаточность», букв. «сокровище») как организационная структура во взаимодействии с другими структурами оформляет «жизненный круг» социального субъекта (от личности до человечества в целом), представляя собой часть действительности, включенной в сферу его жизнедеятельности. Принципом построения тезауруса является особая систематизация информации. Данные в тезаурусе выстраиваются не вертикально - от общего к частному, а горизонтально от своего к чужому. «Свое» является центральным понятием, вбирая в себя общее, а основным «пространственно» дифференцирующим принципом тезауруса является триада «свое - чужое - чуждое», которая составляет скелет тезауруса. Таким образом, «отсюда следует путь исследования процессов тезаурусной саморегулящии, а именно: поддержания своего, освоения чужого, исключение чуждого, а также выявления картины мира как ядра и референта тезауруса» (Луков, 2015: 13; курсив источника. - А. Г., Т. Г.). Устойчивый тезаурус обладает способностью активно поддерживать «свое» и тем самым выстраивает сам себя, навязывая свою инициативу субъекту-хозяину. Активность тезауруса способствует созданию особой независимой культурно-ценностной структуры, которая вмешивается в фильтрацию поступающей информации, блокируя, переиначивая или даже полностью исключая ту ее часть, которая разрушает целостность тезауруса.

Символическим воплощением тезаурусной структуры является шар: «Тезаурус в наиболее общем виде представляется как шар со своим центром... и периферией (подвижной частью, где свое вступает во взаимодействие с чужим и противодействие с чуждым... со своей пограничной областью, где функционируют различные мембраны, пропускающие или ограничивающие продвижение внешней информации во внутренние структуры тезауруса. <..> Внутри сферы стираются объективные представления об иерархии ценностей входящих в нее феноменов, они представляются как объекты равноценные...» (Луков, 2014: 310-311; курсив источника. - А. Г., Т. Г.).

Авторы идеи для обозначения базовых элементов тезауруса используют понятие «концепт», в котором отражен синтез образа и понятия. Часть устойчивых концептов, освоенных субъектом и способствующих замедлению изменений в структуре тезауруса, названы «константами». Системные характеристики тезауруса - полнота, систематичность, ценностная задан- 
ность, оформленное предназначение (ориентировать субъект и обеспечивать его жизнеспособность) и избыточность (противоречивое свойство, которое означает одновременное присутствие в изучаемом необходимого и ненужного, но задающего динамические импульсы знания) (Луков В., Луков Вл.., 2013: 26-27).

Сопоставление тезаурусной методологии с широко используемым системным подходом представляет черты их сходства и отличия (Горелов, Горелова, 2017). Сходство обнаруживается в целостном и комплексном обзоре свойств объекта, поиске существенных и системных связей его структуры. Нам видится несколько различий системного и тезаурусного подходов. Первый стремится к объективности, т. е. пытается полностью исключить ценностный взгляд на объект, в тезаурусе, напротив, именно ценность составляет фокус взгляда на объект. Во-вторых, в отличие от системного подхода, который выявляет и объединяет однопорядковые элементы структуры, тезаурус выстраивает значимое ядро и удаляющуюся от него по принципу «все более чужое» периферию. В-третьих, системная методология предполагает иерархическую картину изучаемого объекта, будь то социум, идея, культурная картина мира и т. п., тогда как тезаурус реализует образ «тезаурусной сферы», внутри которой все качества равноценны. В-четвертых, вследствие подвижности границы «свое - чужое» механизмом ориентация субъекта в окружающем мире становится не детерминистическое, но в большей мере творческое начало. Таким образом, тезаурусы выстраивают субъективно организованное гуманитарное знание, открывая новые возможности его трактовки - из глубины субъективности к объективному обобщению.

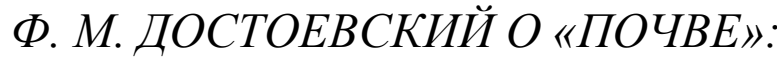 ПЕРВЫЙ ЛИК РУССКОЙ ИДЕИ}

Во втором томе «Заката Европы», вышедшем в 1922 г., О. Шпенглер, говоря о России, сосредоточился на противопоставлении Ф. М. Достоевского и Л. Н. Толстого. Лицо России в восприятии немецкого ученого двоилось, распадалось на исконно русского Достоевского и западника Толстого. Для Шпенглера эти два писателя - антиподы, но, противопоставляя их друг другу, он оговаривается, что «начало и конец сходятся здесь воедино» (Шпенглер, 1998: 201). Он отмечает, что «Достоевский был крестьянин, а Толстой — человек из общества мировой столицы» (там же: 199). Оба утверждения, на первый взгляд, выглядят странновато, но из них можно вывести и более реалистичные выводы. При углубленном взгляде возникает мысль, что в данной интуиции заложен глубокий смысл. Шпенглер уловил, что Достоевский и Толстой представляют собой две стороны самобытной русской мысли. Почвенник Достоевский борется против псевдоморфоза русской цивилиза- 
ции, не боясь подвергнуться обвинениям в излишней русскости. Так как основу русского народа в то время составляли на 9/10 крестьяне, то вставшего на сторону народа Достоевского можно, фигурально выражаясь, отнести к крестьянам. Шпенглер пишет, что Достоевский «никогда не мог внутренне освободиться от земли» (там же), и поэтому его задачей стало выразить народную идею: «Подлинный русский - это ученик Достоевского, хотя он его и не читает... Он сам - часть Достоевского» (там же: 201). Переводя интуицию Шпенглера на рациональный язык, можно сказать, что русская идея Достоевского выражает суть русского характера, тоскующего «по своей собственной жизненной форме, по своей собственной религии, по своей собственной будущей истории. <..> Христианство Достоевского принадлежит будущему тысячелетию» (там же). Интуицию, что Достоевский — это Русь будущая, можно понимать в том смысле, что Россия, освобождаясь от псевдоморфоза, последует по пути русской идеи.

Патриотизм. В нынешних многообразных поисках национальной идеи России не обойтись без гениального писателя и величайшего мыслителя XIX в. Ф. М. Достоевского, который «стал для не-русского мира самым полным, самым сильным, самым ярким выразителем русского духа» (Струве, 1994: 384). Именно он впервые употребил словосочетание «русская идея». Федор Михайлович полагал, что «без высшей идеи не может существовать ни человек, ни нация» (Достоевский, 1994: 389). Еще вопрос (и он философский): идея ли существует для нации, или нация - для идеи, являясь способом ее реализации? Национальная идея - это идеал нации (слово «идеал» произошло от слова «идея»), нравственно-идеологический ориентир, следующий из народного духа.

Национальная идея проистекает из души народа. «Сущность всякой национальности состоит в ее субстанц̧ии, - писал В. Г. Белинский, с которым Достоевский познакомился в самом начале своей литературной деятельности и который имел в тот период на него большое влияние, пребывая властителем дум молодого поколения. - Субстанция есть то непреходимое и вечное в духе народа, которое, само не изменяясь, выдерживает все изменения, целостно и невредимо проходит чрез все фазисы исторического развития. Это зерно, в котором заключается всякая возможность будущего развития. <..> Каждый народ имеет свою субстанцию, как и каждый человек, и в субстанции народа заключается вся его история и его различие от других народов» (Белинский, 1992: 77; курсив источника. - А. Г., Т. Г.). Из вечной субстанции формируется конкретная культурная система, называемая национальной идеей.

Патриотизм писателя - не только сиюминутная любовь к рядом живущему человеку, но и вера в его будущее и особое предназначение: «Нет, 
судите наш народ не по тому, чем он есть, а по тому, чем желал бы стать. А идеалы его сильны и святы, и они-то и спасли его в века мучений; они срослись с душой его искони и наградили ее навеки простодушием и честностью, искренностию и широким всеоткрытым умом, и все это в самом привлекательном гармоническом соединении» (Достоевский, 1994: 49).

То, что автором русской идеи стал Достоевский, связано с обстоятельствами его личной судьбы. Еще в молодости начинающий сочинитель стал посещать кружок, образованный социалистом-утопистом М. В. Петрашевским, в котором обсуждались, в числе прочих, проблемы, поднятые модным в то время утопическим социализмом. Вскоре в Европе грянула революция 1848 г., в 1849 г. члены кружка были арестованы, а некоторые из них, в том числе Федор Михайлович, приговорены к смертной казни, которую заменили каторжными работами с последующим поселением в Сибири. На каторге Достоевский впервые и не по своей воле близко соприкоснулся с простым народом и ужаснулся пропасти между ним и образованными классами. Причину этого писатель нашел в реформах Петра I, которые были нужны, но разъединили народ и образованное сословие, начавшее жить отдельно от основной массы населения «своей собственной, особенной и самостоятельной жизнью» (Достоевский, 1993: 5).

Почвенничество. Достоевский поставил задачу преодоления разрыва между интеллигенцией и народом и стал активным сторонником концепции почвенничества, которая зиждилась на представлении о «национальной почве» как основе социального и духовного развития России. Писатель использовал термин «почва» в значении народного характера. Народ понимался как та «национальная почва», на которую должно встать образованное общество после того, как со времен Петра все по-европейски цивилизованные русские оторвались от национальных корней. Федор Михайлович считал, что после крестьянской реформы возникли условия для сближения правительства и интеллигенции с народом, их мирного сотрудничества и призвал к «всеобщему духовному примирению» и братству сословий в России.

Почвенничество - это не еще одна концепция в дополнение к другим, возникшим прежде, а концепция синтетическая, призванная преодолеть односторонности двух основных в то время направлений общественнополитической мысли России - славянофильства и западничества, стать их синтезом на единой основе - «земле». Славянофильская идея о том, что «разумное развитие народа есть возведение до общечеловеческого значения того типа, который скрывается в самом корне народного бытия» (Хомяков, 2008а: 270; курсив источника. - . Г., Т. Г.), становится у Достоевского одним из его важных положений. Синтетический характер концепции почвенничества переходит и на русскую идею. Почвенничество позволило очер- 
тить контуры «общей идеи», найти платформу, которая примирила бы «цивилизацию» и народное начало. Соединить различные сословия общества русская идея могла, по Федору Михайловичу, на базе представления о самобытном пути России и его всемирном предназначении. При этом русская идея рассматривалась как духовная форма гармоничного развития России, единения народа и образованного общества, включающего власть, интеллигенцию и православное духовенство. Русская идея возникает из концепции почвенничества, но в русскую почву входит присущая русскому человеку способность проникнуться «общечеловеческими интересами».

Русская идея, согласно Достоевскому, в отличие от европейских во всех их разновидностях, исходит из особенностей русского национального характера, из того братского начала, которое в нем есть и которого нет в западном человеке (Достоевский, 1989: 430). Можно при желании свести это различие к старой дилемме европейского индивидуализма и русского коллективизма, если не учитывать, что последний понимается как общечеловеческое единство. Впоследствии Достоевский разовьет свои представления о русской идее, и в речи о Пушкине в 1880 г. скажет о «всемирной отзывчивости» русского человека, который может быть наиболее способен из всех народов вместить в себя идею человеческого единения и братской любви.

Русский социализм. Достоевский создал и социально-политический концепт, отражающий русскую идею, - русский христианский социализм. По Достоевскому, «коммунизм произошел из христианства, из высокого воззрения на человека» и требования коммунизма «реальны» и «истинны» (Неизданный Достоевский ... , 1971: 446). Но в отличие от К. Маркса, который считал, что главные общественно-экономические формации не имеют национального «лица», Достоевский, называя социализм, которым он увлекся в молодости, французским, полагал, что эта общественно-экономическая формация имеет национальную специфику. По его мнению, в основе социального строя лежат религиозные убеждения, и от того, каковы они в данной стране, зависит и характер общественно-экономической формации.

«Национализация» социализма дала возможность писателю выдвинуть представление о русском социализме. По Достоевскому, русский социализм также вытекает не столько из предшествующей ему общественноэкономической формации - капитализма, сколько из христианства, но в православном варианте, придающем ему особую специфику. Русский православный социализм Достоевского представляет собой двойное соответствие: традициям православия и новым социально-политическим веяниям эпохи. «Я говорю про неустанную жажду в народе русском, всегда в нем присущую, великого, всеобщего, всенародного, всебратского единения во имя Христово. $<\ldots>$ Не в коммунизме, не в механических формах заключается социализм 
народа русского: он верит, что спасется лишь в конце концов всесветнылм единением во имя Христово. Вот наш русский социализм!» (Достоевский, 1995: 489; курсив источника. - А. Г., Т. Г.).

Определение Достоевским русского социализма как всеобщего братства во Христе совпадает по сути с определением русской идеи. По мнению Бердяева, Достоевскому «принадлежат самые глубокие мысли о социализме, которые когда-либо были высказаны» (Бердяев, 1994: 89).

Концепцией почвенничества Достоевский заложил основы идеологического единства нации. Русская идея, благодаря ее вселенскости и всечеловечности, стала духовной основой нации и ориентиром ее движения в будущее. Политической формой, призванной установить идеологическое единство русской нации и всемирное братство, служит, по Достоевскому, русская партия. Таким образом, концепция Достоевского содержит в себе три части: исходную духовно-идеологическую - русскую идею, политическое ее продолжение - русскую партию и, наконец, организационное завершение русский социализм. Можно сказать, что в этом «три источника и три составные части» концепции Достоевского. Но русский коммунизм, который пришел на смену русскому православию, оказался далек от того, каким видел русский социализм «пророк русской революции».

От почвенности к универсальности. Русская идея, по Достоевскому, - третья современная мировая идея после католической и протестантской, возможно, третья грядущая перспектива разрешения судеб человеческих: «Следовательно, если национальная идея русская есть, в конце концов, лишь всемирное общечеловеческое единение, то, значит, вся наша выгода в том, чтобы всем, прекратив все раздоры до времени, стать поскорее русскими и национальными» (Достоевский, 1995: 23). Вера в русскую идею ведет к национальному, а затем и всемирному объединению. Так писатель подходит к двум вершинам своей мысли после введения понятия русской идеи - к утверждению «всемирной отзывчивости» русского народа и к представлению о русском социализме.

Достоевский хорошо осознавал актуальность русской идеи в эпоху всеобщего «обособления», поскольку суть ее в преодолении отчуждения различных сословий на основе приобщения к общим народным началам («почве»). Синтез православия с тем положительным, что дали реформы Петра, привел к расширению русской идеи: «...даже в ущерб иногда собственным и крупным ближайшим интересам... <..> ...мы сознали тем самым всемирное назначение наше...» (Достоевский, 1994: 207). Русская идея направлена «на пользу, любовь и службу всему человечеству, на защиту всех слабых и угнетенных в мире» (там же: 272). Этот всечеловеческий отклик, основанный на «инстинкте всежизненности» (Достоевский, 1993: 83), «в русском народе да- 
же сильнее, чем во всех других народах, и составляет его высшую и лучшую характерность» (там же: 82).

Таким образом, тезаурусный анализ русской идеи, сформулированной Достоевским, включает три концепта, формирующих ядро «своего» - почвенность, понимаемую им как цельный народный характер, от которого не надо удаляться, патриотизм как связь с некоей субстанцией, которая составляет неисчезающую и вечную духовную глубину народа (пока этот народ жив), православный социиализм как социальное проявление народного духа. Черты этого лика русской идеи проводят четкую и осмысленную границу между «своим», определяющим основы существования народа, и «чужим», привносимым извне, части которого могут быть осмыслены и избирательно включены внутрь «своего», как это сделал Достоевский в отношении европейской концепции социализма. Устойчивость концептов рассматриваемого лика русской идеи многократно тестировалась историей в годины внешних напастей и войн. История России выступает в этом случае как эмпирическое подтверждение концепции Достоевского и способствует созданию обобщенной, объективной основы русской идеи.

\section{Л. Н. ТОЛСТОЙ О САМООТРЕЧЕНИИ: ВТОРОЙ ЛИК РУССКОЙ ИДЕИ}

Пушкинская речь Ф. М. Достоевского продемонстрировала, что классическая русская литература имела для русской идеи не меньшее значение, чем философская концепция почвенности. Мыслителю приписывают фразу «Все мы вышли из гоголевской “Шинели”», но можно сказать, что и русская идея вышла из слов Н. В. Гоголя «Я брат твой». В число писателей, вышедших из гоголевской «Шинели», можно включить и Л. Н. Толстого, которого Достоевский поставил рядом с А. С. Пушкиным. Рассматривая «Анну Каренину» как совершенное художественное произведение, с которым ничто из европейских литератур в настоящую эпоху не может сравниться, Федор Михайлович добавлял: «...а во-вторых, и по идее своей это уже нечто наше, наше свое родное, и именно то самое, что составляет нашу особенность перед европейским миром, что составляет уже наше национальное “новое слово”...» Милосердия и Любви, «когда преступники и враги вдруг преображаются в существа высшие, в братьев, все простивших друг другу, в существа, которые сами, взаимным всепрощением, сняли с себя ложь, вину и преступность, и тем разом сами оправдали себя с полным сознанием, что получили право на то» (Достоевский, 1995: 236, 238; курсив источника. - А. Г., Т. Г.).

Во время написания «Анны Карениной» с Толстым произошло то, что он назвал «духовным рождением» - внезапное осознание того, что все люди - братья. Лев Николаевич не говорил и не писал о русской идее, но суть его 
«духовного рождения» именно в осознании братства всех людей, что было исходным пунктом и призвано стать конечным результатом осуществления русской идеи: «Если отрицание социального неравенства, обличение неправды господствующих классов есть очень существенный русский мотив, то у Толстого он доходит до предельного религиозного выражения», и поэтому «в русскую идею Л. Толстой входит, как очень важный элемент, без которого нельзя мыслить русского призвания» (Бердяев, 1990: 150).

Лев Николаевич проявлял все основные свойства русского национального характера, на основе которых возникла русская идея, но не упоминая про русскую идею, он тем самым позиционирует себя вне ее. Но вопреки себе он вошел в русскую идею, поскольку последняя, начиная с Достоевского, понимается как имеющая глобальное измерение, ставшее возможным на основе «всемирной отзывчивости» русского человека. «Оба (Достоевский и Толстой. - A. Г., Т. Г.) стремились к Царству Божьему, в которое входит и социальная правда. Для них тема социальная приобретала характер темы религиозной. <..> Такого отречения от своего аристократизма, от своего богатства и, в конце концов, от своей славы Запад не знал. <...> ... Толстой не хочет никакого социального контракта и хочет остаться в правде божественной природы, что и есть исполнение закона Бога» (там же: 149, 166). Писатель не только не собирается отдавать кесарю кесарево, а вообще против царства кесаря: «Он предлагает рискнуть миром для исполнения закона Бога. $<\ldots>$ От православия получил он сознание своей греховности, склонность к неустанному покаянию» (там же: 176, 204). Хотя Толстой отрицал некоторые догматы православия, в основе его духовности лежит православная традиция. Бердяев очень точно осознает, что Толстой входит в русскую идею как бы с другого по сравнению с Достоевским конца - от личности: «Высокая оценка Толстого в истории русской идеи... должна быть связана с его личностью в целом, с его путем, его исканием, с его критикой злой исторической действительности, грехов исторического христианства, с его жаждой совершенной жизни» (там же: 221-222).

Не-патриотизм. В 23 года Толстой пошел добровольцем в армию. Молодой Лев стремился к осмысленному существованию и надеялся обрести его на военной службе. Участвуя в войне на Кавказе, он дважды представлялся к награде Георгиевским солдатским крестом, но по разным причинам не получал его.

Толстой восхищался героизмом русских солдат. В «Севастопольских рассказах» (рассказ «Севастополь в декабре месяце») он пишет о высокой побудительной причине, которая одна заставляет русских людей сражаться: «И эта причина есть чувство, редко проявляющееся, стыдливое в русском, но лежащее в глубине души каждого, — любовь к родине» (Толстой, 1960: 108- 
109). Патриотизм молодого Толстого не подлежит сомнению. Патриотические идеи, которыми были проникнуты «Севастопольские рассказы», он развивает в «Войне и мире», где неоднократно дает высокую оценку действиям русского народа: «...победа нравственная, та, которая убеждает противника в нравственном превосходстве своего врага и в своем бессилии, была одержана русскими под Бородиным. <...> Прямым следствием Бородинского сражения было беспричинное бегство Наполеона из Москвы, возвращение по старой, Смоленской дороге, погибель пятисоттысячного нашествия, и погибель Наполеоновской Франции, на которую в первый раз под Бородиным была наложена рука сильнейшего духом противника» (Толстой, 1940: 265).

Но после «духовного рождения» Лев Николаевич изменил свои взгляды на многие вещи, в том числе и на патриотизм. Исходя из того, что христианская любовь должна быть всеобщей и беспристрастной, христианин не должен быть патриотом, поскольку «христианство не только запрещает всякое убийство, но требует благотворения всем людям, считая всех братьями без различия народностей» (Толстой, 1956а: 50). Чувство патриотизма, по Толстому, «есть, в самом точном определении своем, не что иное, как предпочтение своего государства или народа всякому другому государству и народу...» (там же: 61). Он называет чувство патриотизма «очень глупым и очень безнравственным»: «...глупое потому, что если каждое государство будет считать себя лучше всех других, то очевидно, что все они будут неправы, и безнравственно потому, что оно неизбежно влечет всякого человека, испытывающего его, к тому, чтобы приобрести выгоды для своего государства и народа в ущерб другим государствам и народам...» (там же). И делает вывод, что «патриотизм в самом простом, ясном и несомненном значении своем есть не что иное для правителей, как орудие для достижения властолюбивых и корыстных целей, а для управляемых - отречение от человеческого достоинства, разума, совести и рабское подчинение себя тем, кто во власти» (там же: 65). И государство, по Толстому, изначально противостоит русскому человеку как нечто враждебное.

Фальшивого официального патриотизма во все времена хватало, но история все же свидетельствует, что патриотизм - иммунная система нации, ответственная за уничтожение непрошенных пришельцев, одна из главных опор государства. Через несколько лет начинается Русско-японская война, и 31 декабря 1904 г. Толстой пишет в дневнике: «Сдача Порт-Артура огорчила меня, мне больно. Это патриотизм» (Толстой, 1937: 111). Так, прямо, с обычной для него честностью, он называет овладевшее им чувство, которое прежде приписывал лишь «низшим по нравственному и умственному даже уровню людям» (Толстой, 1956а: 60). По рассудку получается, что «если христианство истина и мы хотим жить в мире, то не только нельзя сочувствовать 
могуществу своего отечества, но надо радоваться ослаблению его и содействовать этому. Надо радоваться, когда от России отделяется Польша, Остзейский край, Финляндия, Армения...» (Толстой, 1958: 51). А сердцу больно. В октябре 1941 г., когда фашисты вплотную приблизились к Москве, М. М. Пришвин написал в дневнике: «...вставай, Лев Николаевич!», уверенный, что тот встал бы на защиту Родины.

Толстой, оставаясь в глубине души вполне русским человеком, пытался подняться выше национального к тому божественному идеалу реальности, в которой «нет ни иудея, ни эллина». Но путь Христа, ведущий к распятию и воскресению, годится далеко не для всех. К толстовскому лику русской идеи русская история поворачивалась в самые сложные периоды жизни народа. По пути Льва Николаевича хотел вести Россию первый министр-председатель Временного правительства князь Львов. Тогда же В.И. Ленин выдвинул идею немедленного отмирания государства после победы социалистической революции, которую он, однако, на практике не торопился осуществить. Второй лик с особой силой заявлял о себе в Смутное время, эпохи крупных народных восстаний, церковного раскола XVII в., а в XX в. и в русской «перестройке». Толстой хотел перескочить через семейный уровень любви к любви вселенской, и через национальный уровень патриотизма - к вселенскому братству. В этом он полностью проявил свой максимализм.

Первая линия связи учения Толстого и русской идеи - духовность, которая пронизывает многие его художественные и религиозно-философские произведения: «Надо жить духовною жизнью для того, чтобы иметь силу управлять своими мыслями. <..> Сила же духовная, сила мысли, нам кажется незначительной, и мы не признаем ее за силу. А между тем в ней-то, в ней одной истинная сила, изменяющая и нашу жизнь, и жизнь всех людей. <..> Перенесение же сознания из телесного существа в духовное совершается усилием мысли» (Толстой, 1956b: 374-375).

Социальность - вторая основополагающая линия сходства учения Толстого с русской идеей. Она оправдывается тем, что дух один во всех людях и он от Бога. Так Лев Николаевич решает вопрос, который многих ставил в тупик: как люди могут быть социально равны, если они не равны биологически. Люди не равны телесно, но равны духовно, и значит они должны быть равны социально: «Если человек живет духовной жизнью, для него не может быть неравенства» (там же: 200). Это христианский и очень русский ответ.

Толстовский лик русской идеи как бы ослеплен божественным светом, и это мешает ему видеть реальную картину жизни. Слова К. Н. Леонтьева о «розовом христианстве» в гораздо большей степени относятся к Толстому, чем к Достоевскому. Можно согласиться с Н. А. Бердяевым, что «Достоевский более сильный мыслитель, чем Толстой, он более знает, он знает проти- 
воположности. Толстой же не умеет повернуть голову, он смотрит вперед по прямой линии» (Бердяев, 1994: 17).

Является ли критика патриотизма Толстым чем-то из ряда вон выходящим для русской идеи? Нет, это свойственно части русской интеллигенции. Раздваивание русской идеи началось уже у В. С. Соловьева, а у Толстого оно усилилось. Корни этого феномена в природе русского человека. Вяч. Иванов, который в статье «О русской идее», интерпретируя название «Третий Рим» в смысле вселенскости русской идеи («ибо “Рим” всегда “вселенная"»; Иванов, 1992: 231), приходит к выводу, что отличительную особенность русской народной психологии составляет «любовь к нисхождению», как «жертвенное низведение божественного света во мрак низшей сферы, ищущей просветления», «склонение перед низшим во всем творении и служение ему...» (там же: 236). Таинственный императив нисхождения кажется русскому поэту начертанным «на челе народа нашего, как его мистическое имя: “уподобление Христу"» (там же: 236-237). В русской национальной идее Вяч. Иванова «раскрывается глубочайший смысл нашего стремления ко всенародности, нашей энергии совлечения, нашей жажды нисхождения и служения» (там же: 237). Это второй закон в личности - закон саморазрушения, который действует наряду с законом самосохранения, и в конечном счете при соблюдении христианских условий нисхождения ведет к воскресению.

В. С. Соловьев находит выход в следующем принципе: «Положительная обязанность по отношению к национальному вопросу: люби (в этическом смысле) все другие народности как свою собственную» (Соловьев, 1988: 69), и поясняет, что это требование вовсе не означает психологической одинаковости чувства, а только этическое равенство волевого отношения. Проблема соотношения национального и всемирного не проста и осуществить принцип «всеобщей любви» нелегко. С. Н. Булгаков предлагает его смягченный вариант: «...исходя из своего национального чувства, не желай зла и не ищи уничтожения и насильственного растворения (ассимиляции) других народов, но признавай их право на существование, как и свое собственное, живи и жить давай другим...» (Булгаков, 1993: 649). Национальное и общечеловеческое в культуре не может быть противопоставляемо, утверждал Н. А. Бердяев. И. А. Ильин дает формулу восхождения от личного через народное к общечеловеческому: «Патриотизм есть правая и верная любовь индивидуального “я” к тому народному “мы”, которое возводит его к великому, общечеловеческому “мы”; это есть реальное, духовное единение человека и народа в великом лоне общечеловеческого» (Ильин, 1994: 256). Любовь к родине совсем не обязательно связана с ненавистью к другим народам и не противоречит любви к Богу. Как считал философ А. Ф. Лосев, можно признать жертву себя родине смыслом человеческого существования. 
Если отказ от вселенскости означает поворот к национализму, то отказ от национального - это путь к гибели нации. Нельзя останавливаться на национальном уровне, но опасно и перескакивать через него, надеясь сразу оказаться на вершине. Необходимо продвигаться последовательно, как советовал А. С. Хомяков в отношении любви. Он пишет, что высший закон любви исполним для весьма малого числа избранных душ: «Таково внутреннее тяготение эгоизма и сравнительная слабость добрых начал» (Хомяков, 2008b: 336). Но сама природа и помогает человеку исполнить, хотя бы в несовершенной степени, этот закон: «...кровная, естественная связь придает слабости человеческой столько сил, что она доходит (хотя, повторяю, в тесных пределах) до самоотрицания эгоизма, то есть до искренней, истинной и деятельной любви» (там же). Так природа и поддерживает эгоизм, и помогает избавлению от него. Алексей Степанович преодолевает здесь антиномию отдельной и всеобщей любви, которая была камнем преткновения для многих мучающихся и не находящих правильного решения мыслителей. Хомяков делает отдельную любовь как бы залогом любви всеобщей, которая может наступить в будущем. Ту же идею можно применить для обоснования возможности гармонии национального и вселенского. Превалирование имперскости в развитии народа искажает первый лик национальной идеи и ему на смену приходит второй, противоположный первому. Выход же в том, чтобы возвышение национального последовательно и неуклонно вело к осуществлению вселенских целей.

В основании не-патриотизма Толстого лежит чувство, устремленное найти выход из земной тривиальности и ошибок в сферу «дольнего», к истинной религиозности и вере. Это горячее чувство любви. Современный непатриотизм движим скорее холодным безразличием ко всему, включая и то, что по природе призвано вызывать любовь - к семье, к земле, на которой родился, к людям, с которыми жил бок о бок, к традиции и культуре, которые позволили «вылупиться» любимому Я. Не ненависть, обида или гнев, а «нелюбовь» (очень точная характеристика современной жизни, данная режиссером А. П. Звягинцевым) и следующий за ней цинизм все больше заполняют социальное пространство нашей жизни.

Правильному решению возникающих здесь антиномий помогает тезаурусная триада «свое - чужое - чуждое». Любовь к «своему» - родной природе, характеру народа (с его позитивными и негативными чертами), духовная связь с русским миром - сталкивается с «нелюбовью» к «чужому», которое отчасти может быть освоено и включено внутрь. Особенно влиятельным и агрессивным становится внедрение «чуждого», усиливающееся в глобальном мире и часто выполняющее роль духовной (а также социальнополитической) «пятой колонны», разрушающей национальный мир изнутри. 
В зоне «чуждого», за пределами двух ликов русской идеи оказываются, с одной стороны, националисты, а с другой, те, кто как В. В. Розанов (который сам определил свое положение как «возле русской идеи»), К. Н. Леонтьев и Д. С. Мережковский, который, начав с идеи обновления христианства и критики взглядов Достоевского на русскую идею, кончил тем, что призвал в 1941 г. «германский гений к победе над большевизмом».

Проблема национального самоотречения. Не сам Толстой, но продолжающий его идеи не-патриотизма и отказа от государства В. С. Соловьев приходит к необходимости национального самоотречения России в целях достижения всеединства человечества. Позже Д. С. Мережковский доводит эту идею до антипатриотизма, выразив надежду «на величайшие бедствия, может быть, гибель России как самостоятельного политического тела...» (Мережковский, 1991: 349).

Н. Я. Данилевский, напротив, был сторонником несводимости самобытных культурно-исторических типов друг к другу и их полноценного свободного развития. Государство не может исходить из соображений нравственности и, стало быть, требования самопожертвования, так как в отличие от конкретного человека «государство и народ суть явления преходящие, существующие только во времени, и, следовательно, только на требовании этого их временного существования могут основываться законы их деятельности, то есть политики» (Данилевский, 1991: 34).

История рассудила спор двух гениев. В конце ХХ века Россия, можно сказать, осуществила свое национальное самоотречение, которое выразилось не только в отказе от собственных форм жизни, но и в попытке перейти на формы, присущие западному культурно-историческому типу, что вело к потере ничем невосполнимой самобытности. В «перестройке», обернувшейся «катастройкой», восторжествовал второй лик русской идеи. А перед глазами был пример поднявшегося в полный рост Китая, который до сих пор совершенно не принимается в расчет нашей элитой, несмотря на свою эффективность. В эпоху «перестройки» подтвердилась правота слов Данилевского о том, что если бы Россия перестала «внимать не только голосу народной чести, но и самым громким побуждениям инстинкта самосохранения», отказалась «от всех преданий своей истории», отреклась «от самого смысла своего существования», то и тогда Запад не оставил бы ее в покое (там же: 435).

После 1991 г. изменился общественный строй России, ее отношение к Западу стало благожелательным. Запад же сделал все возможное, чтобы благодаря изменениям в России усилиться самому и в то же время ослабить ее как можно больше. Вот к чему привело национальное самоотречение или, как еще называл это Данилевский, «духовное самопожертвование»! В ответ на национальное самоотречение России Америка заявила о своей исключи- 
тельности, руководстве мировым сообществом и стала диктовать всему миру свою волю, развязывая войны против суверенных государств и сея «организованный хаос» на планете.

То национальное самоотречение, которое Соловьев считал миссией русского народа, привело к самоунижению всего русского как низшего по отношению к западному, искажению национальной жизни, в которой непропорционально большое место заняло все иностранное - от западной моды до голливудских фильмов, создавая питательную среду для размножения «пятой колонны». Чуждое проникло в живое тело русской жизни. Тридцатилетний период самоотречения не дал России ничего, кроме позора. С ней стали разговаривать, как с третьесортной державой, и даже союзники отвернулись от нее. Где же гармония, о которой мечтал Соловьев? Гармония может наступить, если к этому стремятся обе стороны, а Запад воспользовался добровольным ослаблением России для того, чтобы попытаться стать властителем мира.

Критикуя концепцию самоотречения, Данилевский как бы полемизировал с более поздней точкой зрения Толстого на патриотизм. И это не чисто теоретический спор. Программа национального самоотречения по существу была принята большевиками, как и «прорабами перестройки» при разрушении СССР. Очень актуально звучат слова Данилевского об отношении Европы к России: «Европа не знает, потому что не хочет знать, или, лучше сказать, знает так, как знать хочет, то есть как соответствует ее предвзятым мнениям, страстям, гордости, ненависти и презрению. <..> . . Европа не признает нас своими. Она видит в России и в славянах вообще $<\ldots>$ враждебное начало. <..> Вот единственное удовлетворительное объяснение той двойственности меры и весов, которыми отмеривает и отвешивает Европа, когда дело идет о России (и не только о России, но вообще о славянах)...» (Данилевский, 1991: 50-51). Поэтому как бы мы ни стремились стать Европой, как бы нынешние руководители Украины ни восклицали, что она - Европа, этого русскому миру не дано, поскольку мы принадлежим к разным с Западом культурно-историческим типам. А то, что коренной чертой романогерманского типа является насильственность и направляется она именно на нас как ей чуждых, придает дополнительные трудности нашему взаимопониманию.

Совершив национальное самоотречение, Россия потеряла свою субъектность на международной арене, отказалась от суверенности своей внешней и внутренней политики, превратившись в сырьевой придаток Запада. Встретились два потока - идущее изнутри национальное самоотречение России и пришедшее извне давление Запада, - и произошел геополитический взрыв, волны от которого до сих пор обходят земной шар. Первая волна 
в 1990-е гг. привела к разрушению СССР и Югославии, вторая в нулевые годы - к разрушению государственности в странах Ближнего Востока, третья в текущее десятилетие - к войне в Сирии и Украине. Сошлись воедино различные субъективные факторы, наложившись на объективные. Россия опять победила себя в смысле изменения сознания большинства населения из-за перерождения элиты, наивности русского народа и роста националистических настроений на ее окраинах. Меньшинство проявило агрессивноразрушительную силу, а большинство, как не раз было раньше, промолчало. И те, и другие (в неравной степени) стали палачами своей Родины.

Базовые концепты второго лика русской идеи - отход от патриотизма и самоотречение - как бы пытаются отыскать границы «своего» и «чужого». Патриотизм с его любовью к земле, на которой живешь, с ее рельефом, растениями, животными, ее историей и всеми разнообразными событиями, которые на ней происходили, к народу, который ее населяет со всеми его особенностями и свойствами характера - это уютное чувство определенного, своего, мира. По Толстому и Соловьеву, оно должно быть разрушено для принятия «чужого» - огромного мира всего человечества и рождения нового чувства — «планетарного патриотизма». Глобализация мира в целом и глобальность экологической проблемы все настойчивее подводят человечество к такому миропониманию. Второй лик русской идеи фактически стал его предтечей.

\section{ЗАКЛЮЧЕНИЕ:}

\section{ДВА ЛИКА РУССКОЙ ИДЕИ}

Путь Достоевского - это путь коллективного спасения нации, вдохновленного русской идеей. Путь же Толстого - это путь индивидуального примера «духовного рождения». «Человек из общества мировой столицы» в душе тоже крестьянин, разве что ставший в столице чуть менее деревенским жителем, чем Достоевский. Он не только и не столько антипод Федора Михайловича, сколько составляет с ним единое целое (недаром после смерти Достоевского он сказал, что это был самый близкий ему человек). Толстой не «всего лишь новая форма псевдоморфоза» (Шпенглер, 1998: 201). Творец «Войны и мира» также мыслил в рамках русской идеи, но в отличие от Достоевского не искал «земли» как основы существования в этом мире, а искал Бога как основы личной духовности, и в конце концов обрел его.

Идеи толстовского гения не могут не войти в русскую идею, поскольку последняя, начиная с Достоевского, понимается как имеющая глобальное измерение, ставшее возможным на основе «всемирной отзывчивости» русского человека. Достоевский соединил в русской идее русскость и общечеловечность. Надо быть русским, чтобы стать всечеловеком, заявил он. Федор Ми- 
хайлович акцентировал внимание на первой части своего утверждения русскости. Толстой основное внимание уделил общечеловечности русской идеи. Религиозное начало, о котором пишет Лев Николаевич, и есть русская идея, прямым и бескорыстным выразителем которой он являлся.

Различие двух ликов русской идеи проявляется, с одной стороны, в признании русского народа единственным носителем правды, a, с другой стороны, призывом к его самоотречению. Позиции двух мыслителей высвечивают дуальность, но не двуличность русской идеи, потому что оба были предельно искренни, а их идеи проистекают из «страстной русскости». Русская идея, лики которой обозначены Достоевским и Толстым, может стать основой широкой общенациональной духовной практики.

Можно сказать, что современная действительность и русская идея две вещи несовместные. Тем не менее русский народ продолжает существовать, и вопрос «Как ему жить?» остается. «Деятельность народа, как деятельность человека, должна быть самостоятельна», - писал К. С. Аксаков (Аксаков, 1992: 114; курсив источника. - А. Г., Т. Г.). Если забудут русскую идею, то не будет и России как духовно-социального образования.

\section{СПИСОК ЛИТЕРАТУРЫ}

Аксаков, К. С. (1992) Еще несколько слов о русском воззрении // Русская идея / сост. и авт. вступ. ст. М. А. Маслин. М. : Республика. 496 с. С. 112-117.

Белинский, В. Г. (1992) Россия до Петра Великого // Русская идея : антология / сост. и авт. вступ. ст. М. А. Маслин. М. : Республика. 496 с. С. 74 90.

Бердяев, Н. А. (1990) Русская идея. Основные проблемы русской мысли XIX века и начала XX века // О России и русской философской культуре: философы русского послеоктябрьского зарубежья / отв. ред. Е. М. Чехарин. М. : Наука. 528 с. С. 43-271.

Бердяев, Н. А. (1994) Миросозерцание Достоевского // Бердяев Н. А. Философия творчества, культуры, искусства : в 2 т. / сост. Р. А. Гальцева. М. : Искусство. Т. 2.510 с. С. 7-150.

Булгаков, С. Н. (1993) Нация и человечество // Булгаков С. Н. Соч. : в 2 т. М. : Наука. Т. 2.752 с. С. 644-653.

Горелов, А. А. (2014) Глобальный неоколониализм и русская идея. М. : ЛЕНАНД. 256 с.

Горелов, А. А., Горелова, Т. А. (2017) Тезаурусная структура цивилизационных концепций Н. Я. Данилевского и О. Шпенглера // Тезаурусы и тезаурусная сфера: II Академические чтения памяти Владимира Андреевича Лукова, 29 марта 2017 г. : сб. науч. трудов / ред. кол. В. А. Луков (отв. ред.), 
Н. В. Захаров, Т. Ф. Кузнецова, В. Н. Трыков. М. : Изд-во Моск. гуманит. унта. 256 с. С. $43-56$.

Горелова, Т. А. (2015) Тезаурус русского национального характера [Электронный ресурс] // Научные труды Московского гуманитарного университета. № 4. C. 14-27. URL: http://journals.mosgu.ru/trudy/article/view/46 (дата обращения: 25.03.2019). DOI: 10.17805/trudy.2015.4.2

Данилевский, Н. Я. (1991) Россия и Европа / сост., послесловие и комм. С. А. Вайгачева. М. : Книга. 574 с.

Достоевский, Ф. М. (1989) Зимние заметки о летних впечатлениях // Достоевский Ф. М. Собр. соч. : в 15 т. Л. : Наука. Т. 4: Униженные и оскорбленные ; Повести и рассказы, 1862-1866 ; Игрок. 783 с. С. 388-451.

Достоевский, Ф. М. (1993) Собр. соч. : в 15 т. СПб. : Наука. Т. 11: Публицистика 1860-х годов. 571 с.

Достоевский, Ф. М. (1994) Собр. соч. : в 15 т. СПб. : Наука. Т. 13: Дневник писателя. 1876 г. 541 с.

Достоевский, Ф. М. (1995) Собр. соч. : в 15 т. СПб. : Наука. Т. 14: Дневник писателя. 1877, август 1880, 1881 г. 783 с.

Иванов, Вяч. (1992) О русской идее // Русская идея / сост. и авт. вступ. ст. М. А. Маслин. М. : Республика. 496 с. С. 227-240.

Ильин, И. А. (1994) О сущности правосознания // Ильин И. А. Собр. соч. : в 10 т. М. : Русская книга. Т. 4. 620, [1] с. С. 149-414.

Луков, В. А. (2015) Владимир Андреевич Луков и становление тезаурусной методологии гуманитарных исследований // Мировая культура в русском тезаурусе: I Академические чтения памяти Владимира Андреевича Лукова, 27 марта 2015 г. : сб. науч. трудов / редкол.: В. А. Луков (отв. ред.), Н. В. Захаров, Т. Ф. Кузнецова и др. М. : Изд-во Моск. гуманит. ун-та. 280 с. C. 3-29.

Луков, В. А., Луков, Вл. А. (2013) Тезаурусы II: Тезаурусный подход к пониманию человека и его мира : науч. монография. М. : Изд-во Нац. ин-та бизнеса. $640 \mathrm{c}$.

Луков, Вл. А. (2014) Концепция тезаурусных сфер // Знание. Понимание. Умение. № 1. С. 307-326.

Мережковский, Д. С. (1991) В тихом омуте : статьи и исследования разных лет. М. : Советский писатель. 489, [2] с.

Неизданный Достоевский: Записные книжки и тетради 1860-1881 гг. (1971) / АН СССР. Ин-т мировой лит. им. А. М. Горького ; ред. И. С. Зильберштейн, Л. М. Розенблюм. М. : Наука. 727 с.

Соловьев, В. С. (1988) Оправдание добра. Нравственная философия // Соловьев В. С. Соч. : в 2 т. / сост., общ. ред. и вступ. ст. А. Ф. Лосева, 
А. В. Гулыги, примеч. С. Л. Кравца, Н. А. Кормина. М. : Мысль. Т. 1. 892, [2] c. C. $47-548$.

Струве, П. Б. (1994) Достоевский — путь к Пушкину // Русская идея: в кругу писателей и мыслителей Русского зарубежья : в 2 т. / сост. В. М. Пискунов ; коммент. Н. Б. Злобина. М. : Искусство. Т. 2. 684 с. С. $383-$ 386.

Толстой, Л. Н. (1937) Полн. собр. соч. : в 90 т. / под общ. ред. В. Г. Черткова. Изд., испр. и доп. М. : Худож. лит. Т. 55: Дневники и записные книжки 1904-1906. ХI, 633 с.

Толстой, Л. Н. (1940) Полн. собр. соч. : в 90 т. / под общ. ред. В. Г. Черткова. Изд., испр. и доп. М. : Худож. лит. Т. 11: Война и мир. Т. 3. $465 \mathrm{c}$.

Толстой, Л. Н. (1956а) Христианство и патриотизм // Толстой Л. Н. Полн. собр. соч. : в 90 т. / под общ. ред. В. Г. Черткова. Изд., испр. и доп. М. : Худож. лит. T. 39. XL, 260 с. С. 27-80.

Толстой, Л. Н. (1956b) Полн. собр. соч. : в 90 т. / под общ. ред. В. Г. Черткова. Изд., испр. и доп. М. : Худож. лит. Т. 45: [Путь жизни. 1910]. $601 \mathrm{c}$.

Толстой, Л. Н. (1958) Патриотизм или мир? // Толстой Л. Н. Полн. собр. соч. : в 90 т. / под общ. ред. В. Г. Черткова. Изд., испр. и доп. М. : Худож. лит. Т. 90. Серия 1-3: [Произведения, дневники, письма. 1835-1910]. 475 с. С. $45-$ 53.

Толстой, Л. Н. (1960) Собр. соч. : в 20 т. / под общ. ред. Н. Н. Акоповой [и др.]. М. : Гослитиздат. Т. 2: Повести и рассказы. 1852-1856 гг. 454 с.

Хомяков, А. С. (2008а) «Обязанность самобытного развития». Замечания на статью г. Соловьева «Шлецер и антиисторическое направление» // Хомяков А. С. Всемирная задача России / сост. и ком. М. М. Панфилова ; отв. ред. О. А. Платонов. М. : Ин-т русской цивилизации. 784 с. С. 253-270.

Хомяков, А. С. (2008b) Нравственность жизни «частной, общественной и гражданской». Письмо к издателю Т. И. Филиппову // Хомяков А. С. Всемирная задача России / сост. и ком. М. М. Панфилова ; отв. ред. О. А. Платонов. М. : Ин-т русской цивилизации. 784 с. С. 328-345.

Шпенглер, О. (1998) Закат Европы. Очерки морфологии мировой истории. 2. Всемирно-исторические перспективы / пер. с нем. и примеч. И. И. Маханькова. М. : Мысль. 606, [1] с.

Дата поступления: 20.04.2019 г. 


\section{REFERENCES}

Aksakov, K. S. (1992) Eshche neskol'ko slov o russkom vozzrenii [Some more words on the Russian outlook]. In: Russkaia ideia [The Russian idea] / comp. and the opening chapter by M. A. Maslin. Moscow : Respublika Publ. 496 p. Pp. 112-117. (In Russ.).

Belinsky, V. G. (1992) Rossiia do Petra Velikogo [Russia before Peter the Great]. In: Russkaia ideia [The Russian idea] / comp. and the opening chapter by M. A. Maslin. Moscow : Respublika Publ. 496 p. Pp. 74-90. (In Russ.).

Berdyaev, N. A. (1990) Russkaia ideia. Osnovnye problemy russkoi mysli XIX veka i nachala XX veka [The Russian idea. The main issues of the Russian thought of the 19th century and the early 20th century]. In: O Rossii $i$ russkoi filosofskoi kul'ture: filosofy russkogo posleoktiabr'skogo zarubezh'ia [On Russia and Russian philosophical culture: Philosophers of the Russian post-October émigré community] / ed. by E. M. Chekharin. Moscow : Nauka Publ. 528 p. Pp. 43271. (In Russ.).

Berdyaev, N. A. (1994) Mirosozertsanie Dostoevskogo [Dostoevsky's worldview]. In: Berdyaev N. A. Filosofiia tvorchestva, kul'tury, iskusstva [Philosophy of creativity, culture, art] : in 2 vols. / comp. by R. A. Galtseva. Moscow : Iskusstvo Publ. Vol. 2. 510 p. Pp. 7-150. (In Russ.).

Bulgakov, S. N. (1993) Natsiia i chelovechestvo [Nation and mankind]. In: Bulgakov S. N. Sochineniia [Works] : in 2 vols. Moscow : Nauka Publ. Vol. 2. 752 p. Pp. 644-653. (In Russ.).

Gorelov, A. A. (2014) Global'nyi neokolonializm i russkaia ideia [Global neocolonialism and the Russian idea]. Moscow : LENAND Publ. 256 p. (In Russ.).

Gorelov, A. A. and Gorelova, T. A. (2017) Tezaurusnaia struktura tsivilizatsionnykh kontseptsii N. Ia. Danilevskogo i O. Shpenglera [Thesaurus structure of civilizational conceptions of N. Ya. Danilevsky and O. Spengler]. In: Tezaurusy $i$ tezaurusnaia sfera [Thesauri and thesaurus sphere] : The 2nd Academic Readings in the memory of Vladimir Andreevich Lukov, March 29, 2017 : Collection of articles / editorial board: V. A. Lukov (publishing editor), N. V. Zakharov, T. F. Kuznetsova, Ch. K. Lamazhaa and V. P. Trykov. Moscow : Moscow University for the Humanities Publ. 256 p. Pp. 43-56. (In Russ.).

Gorelova, T. A. (2015) Tezaurus russkogo natsional'nogo kharaktera [Thesaurus of Russian national character]. Nauchnye trudy Moskovskogo gumanitarnogo universiteta, no. 4, pp. 14-27. URL: http://journals.mosgu.ru/trudy/article/ view/46 (accessed 25.03.2019). DOI: 10.17805/trudy.2015.4.2 (In Russ.).

Danilevsky, N. Ya. (1991) Rossiia i Evropa [Russia and Europe] / comp., afterword and comm. by S. A. Vaigachev. Moscow : Kniga Publ. 574 p. (In Russ.). 
Dostoevsky, F. M. (1989) Zimnie zametki o letnikh vpechatleniiakh [Winter notes on summer impressions]. In: Dostoevsky F. M. Sobranie sochinenii [Collected works] : in 15 vols. Leningrad : Nauka Publ. Vol. 4: Unizhennye i oskorblennye ; Povesti i rasskazy, 1862-1866; Igrok [Humiliated and insulted; Novellas and short stories, 1862-1866; The gambler]. 783 p. Pp. 388-451. (In Russ.).

Dostoevsky, F. M. (1993) Sobranie sochinenii [Collected works] : in 15 vols. St. Petersburg : Nauka Publ. Vol. 11: Publitsistika 1860-kh godov [Publicistic writings of the 1860s]. 571 p. (In Russ.).

Dostoevsky, F. M. (1994) Sobranie sochinenii [Collected works] : in 15 vols. St. Petersburg : Nauka Publ. Vol. 13: Dnevnik pisatelia. 1876 g. [A writer's diary. 1876]. 541 p. (In Russ.).

Dostoevsky, F. M. (1995) Sobranie sochinenii [Collected works] : in 15 vols. St. Petersburg : Nauka Publ. Vol. 14: Dnevnik pisatelia. 1877, avgust 1880, 1881 g. [A writer's diary. 1877, August 1880, 1881]. 783 p. (In Russ.).

Ivanov, Viach. (1992) O russkoi idee [On the Russian idea]. In: Russkaia ideia [The Russian idea] / comp. and opening chapter by M. A. Maslin. Moscow : Respublika Publ. 496 p. Pp. 227-240. (In Russ.).

Ilyn, I. A. (1994) O sushchnosti pravosoznaniia [On the essence of legal conscience]. In: Ilyn I. A. Sobranie sochinenii [Collected works] : in 10 vols. Moscow : Russkaia kniga Publ. Vol. 4. 620, [1] p. Pp. 149-414. (In Russ.).

Lukov, V. A. (2015) Vladimir Andreevich Lukov i stanovlenie tezaurusnoi metodologii gumanitarnykh issledovanii [Vladimir Andreevich Lukov and the rise of the thesaurus methodology of humanities studies]. In: Mirovaia kul'tura v russkom tezauruse [World culture in the Russian thesaurus] : The 1st Academic Readings in the memory of Vladimir Andreevich Lukov, March 27, 2015 : Collection of articles / editorial board: V. A. Lukov (publishing editor), N. V. Zakharov, T. F. Kuznetsova, Ch. K. Lamazhaa and V. P. Trykov. Moscow : Moscow University for the Humanities Publ. 280 p. Pp. 3-29. (In Russ.).

Lukov, V. A. and Lukov, Vl. A. (2013) Tezaurusy II: Tezaurusnyi podkhod $k$ ponimaniiu cheloveka i ego mira [Thesauri II: The thesaurus approach to the conceptualization of the person and his/her world]. Moscow : The National Institute of Business Publ. 640 p. (In Russ.).

Lukov, Vl. A. (2014) Kontseptsiia tezaurusnykh sfer [The conception of thesaurus spheres]. Znanie. Ponimanie. Umenie, no. 1, pp. 307-326. (In Russ.).

Merezhkovsky, D. S. (1991) V tikhom omute : stat'i i issledovaniia raznykh let [In still water: Articles and research works of various years]. Moscow : Sovetskii pisatel' Publ. 489, [2] p. (In Russ.).

Neizdannyi Dostoevskii: Zapisnye knizhki i tetradi 1860-1881 gg. [Unpublished Dostoevsky: Diaries and notebooks, 1860-1881] (1971) / Academy of 
Sciences of the USSR. Gorky Institute of World Literature ; ed. by I. S. Zilbershtein and L. M. Rozenblium. Moscow : Nauka Publ. 727 p. (In Russ.).

Soloviev, V. S. (1988) Opravdanie dobra. Nravstvennaia filosofiia [Justification of the good. Moral philosophy]. In: Soloviev V. S. Sochinenia [Works] : in 2 vols. / comp., ed. and opening chapter by A. F. Losev and A. V. Gulyga, notes by L. Kravts and N. A. Kormin. Moscow : Mysl' Publ. Vol. 1. 892, [2] p. Pp. 47-548. (In Russ.).

Struve, P. B. (1994) Dostoevskii — put' k Pushkinu [Dostoevsky — The way to Pushkin]. In: Russkaia ideia: v krugu pisatelei i myslitelei Russkogo zarubezh'ia [The Russian idea: In the circle of writers and thinkers of the Russian émigré community] : in 2 vols. / comp. by. V. M. Piskunov; comm. by N. B. Zlobin. Moscow : Iskusstvo Publ. Vol. 2. 684 p. Pp. 383-386. (In Russ.).

Tolstoy, L. N. (1937) Polnoe sobranie sochinenii [Complete works] : in 90 vols. / ed. by V. G. Chertkov. Revised and enlarged edn. Moscow : Khudozhestvennaia literatura Publ. Vol. 55: Dnevniki i zapisnye knizhki 19041906 [Diaries and notebooks, 1904-1906]. XI, 633 p. (In Russ.).

Tolstoy, L. N. (1940) Polnoe sobranie sochinenii [Complete works] : in 90 vols. / ed. by V. G. Chertkov. Revised and enlarged edn. Moscow : Khudozhestvennaia literatura Publ. Vol. 11: Voina i mir. T. 3 [War and Peace, vol. 3]. 465 p. (In Russ.).

Tolstoy, L. N. (1956a) Khristianstvo i patriotizm [Christianity and patriotism]. In: Tolstoy L. N. Polnoe sobranie sochinenii [Complete works] : in 90 vols. / ed. by V. G. Chertkov. Revised and enlarged edn. Moscow : Khudozhestvennaia literatura Publ. Vol. 39. XL, 260 p. Pp. 27-80. (In Russ.).

Tolstoy, L. N. (1956b) Polnoe sobranie sochinenii [Complete works] : in 90 vols. / ed. by V. G. Chertkov. Revised and enlarged edn. Moscow : Khudozhestvennaia literatura Publ. Vol. 45: Put' zhizni. 1910 [The way of life. 1910]. 601 p. (In Russ.).

Tolstoy, L. N. (1958) Patriotizm ili mir? [Patriotism or peace?]. In: Tolstoy L. N. Polnoe sobranie sochinenii [Complete works] : in 90 vols. / ed. by V. G. Chertkov. Revised and enlarged edn. Moscow : Khudozhestvennaia literatura Publ. Vol. 90. Series 1-3: Proizvedeniia, dnevniki, pis'ma. 1835-1910 [Writings, diaries, letters. 1835-1910]. 475 p. Pp. 45-53. (In Russ.).

Tolstoy, L. N. (1960) Sobranie sochinenii [Complete works] : in 20 vols. / ed. by N. N. Akopova et al. Moscow : Goslitizdat Publ. Vol. 2: Povesti i rasskazy. 1852-1856 gg. [Novellas and short stories, 1852-1856]. 454 p. (In Russ.).

Khomyakov, A. S. (2008a) «Obiazannost' samobytnogo razvitiia». Zamechaniia na stat'iu g. Solov'eva «Shletser i antiistoricheskoe napravlenie» ["Obligation of indigenous development". Remarks on the article "Schlözer and antihistorical movement" by Mr. Soloviev]. In: Khomyakov A. S. Vsemirnaia zadacha 
Rossii [Global task of Russia] / comp. and comm. by M. M. Panfilov; ed. by O. A. Platonov. Moscow : Institute of Russian Civilization Publ. 784 p. Pp. 253-270. (In Russ.).

Khomiakov, A. S. (2008b) Nravstvennost' zhizni «chastnoi, obshchestvennoi i grazhdanskoi». Pis'mo k izdateliu T. I. Filippovu [The morality of life, "private, public and civil". A letter to publisher T. I. Filippov]. In: Khomiakov A. S. Vsemirnaia zadacha Rossii [Global task of Russia] / comp. and comm. by M. M. Panfilov ; ed. by O. A. Platonov. Moscow : Institute of Russian Civilization Publ. 784 p. Pp. 328-345. (In Russ.).

Spengler, O. (1998) Zakat Evropy. Ocherki morfologii mirovoi istorii. 2. Vsemirno-istoricheskie perspektivy [The decline of the West. Essays on the morphology of world history. 2. Global and historical perspective] / transl. from German and notes by I. I. Makhankov. Moscow : Mysl' Publ. 606, [1] pp. (In Russ.).

Submission date: 20.04.2019.

Горелов Анатолий Алексеевич - доктор философских наук, ведущий научный сотрудник Института философии РАН. Адрес: 119842, Россия, г. Москва, ул. Гончарная, д. 12. Тел.: +7 (495) 697-91-28. Эл. адрес: evolepis@iph.ras.ru

Горелова Татьяна Анатольевна - доктор философских наук, профессор кафедры философии, культурологии и политологии Московского гуманитарного университета. Адрес: 111395, Россия, г. Москва, ул. Юности, 5. Тел.: +7 (499) 374-55-11. Эл. адрес: fylosofy@mosgu.ru

Gorelov Anatoliy Alekseevich, Doctor of Philosophy, Leading Research Fellow, Institute of Philosophy, Russian Academy of Sciences. Postal address: 12, Goncharnaya St., 119842 Moscow, Russian Federation. Tel.: +7 (495) 697-91-28. E-mail: evolepis@iph.ras.ru

Gorelova Tatyana Anatolievna, Doctor of Philosophy, Professor, Department of Philosophy, Culturology and Politology, Moscow University for the Humanities. Postal address: 5, Yunosti St., 111395 Moscow, Russian Federation. Tel.: +7 (499) 374-55-11. E-mail: fylosofy@mosgu.ru

\section{Для ичитирования:}

Горелов А. А., Горелова Т. А. Два лика русской идеи в свете тезаурусного подхода [Электронный ресурс] // Горизонты гуманитарного знания. 2019. № 2. C. 21-44. URL: http://journals.mosgu.ru/ggz/article/view/1002 (дата обращения: дд.мм.гггг). DOI: $\underline{10.17805 / \mathrm{ggz} .2019 .2 .2}$ 